\title{
PENGUKURAN BEBAN KERJA TENAGA KERJA \\ DENGAN METODE WORK SAMPLING \\ (Studi Kasus di PT. XY Yogyakarta)
}

\author{
Jono \\ Jurusan Teknik Industri \\ Universitas Widya Mataram Yogyakarta \\ Yonuwm@yahoo.co.id
}

\begin{abstract}
ABSTRAK
PT XY sebagai salah satu perusahaan penghasil mebel memiliki kendala tenaga kerja sehingga diperlukan adanya penanganan khusus terhadap permasalahan tenaga kerja. Tenaga kerja di Assembling Departement khususnya stasiun meja makan terjadi kelebihan beban kerja sehingga tidak bisa memenuhi target produksi. Untuk memperbaiki beban kerja maka diusulkan bagaimana dilakukan pengukuran kerja dengan metode work sampling. Penelitian ini bertujuan menentukan waktu baku, produksi standar, beban kerja tenaga kerja dan jumlah tenaga kerja yang diperlukan.

Work sampling adalah suatu teknik untuk mengadakan sejumlah besar pengamatan terhadap aktivitas kerja dari pekerja. Pengamatan aktivitas kerja untuk selang waktu yang diambil secara acak terhadap satu atau lebih pekerja dan kemudian mencatatnya apakah pekerja dalam keadaan bekerja atau menganggur. Pengukuran beban kerja tenaga kerja dengan metode work sampling untuk menghitung waktu baku, produksi standar, beban kerja dan jumlah tenaga kerja yang diperlukan.

Dari hasil pengolahan data didapatkan waktu baku 298,92 menit, produksi standar yakni 7 per lima hari unit meja, beban kerja tenaga kerja sebesar 92,42\% dan jumlah tenaga kerja yang diperlukan 6 orang.
\end{abstract}

Kata kunci : Work Sampling, Beban Kerja, Tenaga Kerja.

\section{PENDAHULUAN}

Perekonomian bangsa Indonesia sekarang ini sedang mengalami pasang surut. Hal ini akan berdampak pada terhambatnya perkembangan industri ditanah air. Perusahaan harus menanggung biaya produksi untuk menghasilkan produk yang berkualitas agar diminati konsumen. Untuk mempertahankan dari krisis ini, perusahaan melakukan pemutusan hubungan kerja kepada beberapa karyawannya.

Disamping itu perkembangan industri yang sangat pesat dewasa ini menuntut sebuah perusahaan untuk bersaing didunia usahanya agar dapat memperoleh keuntungan yang maksimal. Salah satu cara untuk mengantisipasi persaingan usaha saat ini khususnya dalam industri manufaktur adalah berupaya mengelola sumber daya yang dimiliki perusahaan.

Perusahaan dalam menjalankan kegiatan produksinya, harus selalu berusaha untuk memanfaatkan sebaik mungkin sumber daya yang dimiliki karyawan produksi sebagai komponen penting dalam kegiatan produksi harus ditingkatkan. Produktivitas tenaga kerja sesuai dengan skill (keterampilan), pengetahuan dan pengalaman yang dimiliki. Peranan karyawan produksi pada stasiun kerja perlu mendapat perhatian dari pihak manajemen perusahaan.

Industri mebel sebagai salah satu usaha padat karya, merupakan unit usaha industri yang banyak dikembangkan, sebab memiliki nilai jual tinggi. PT XY adalah perusahaan mebel yang memproduksi meja dan almari. Perusahaan ini memasarkan hasil produksinya sampai kemanca negara. Bidang usaha ini mempunyai pesaing yang cukup banyak, sehingga untuk meraih pasar diperlukan adanya produk yang berkualitas dan memberikan pelayanan yang cepat sesuai dengan waktu yang diperlukan. 
PT XY sebagai salah satu penghasil mebel memiliki banyak kendala, diantaranya kendala tenaga kerja. Tenaga kerja di Assembling Departement khususnya stasiun meja makan terjadi kelebihan beban kerja sehingga tidak bisa memenuhi target produksi. Untuk memperbaiki beban kerja maka diusulkan bagaimana dilakukan pengukuran kerja dengan metode work sampling.

Metode work sampling memiliki akurasi yang lebih, karena data yang diambil secara langsung dilokasi pekerjaan, sehingga faktor-faktor perlakuan yang diukur dapat diketahui secara mendetail. Kedekatan antara peneliti dan pekerja dapat memberikan instruksiinstruksi yang lebih mudah dijalankan oleh karyawan serta mengurangi pengambilan data yang kurang sesuai misalnya pekerja melakukan usaha berlebih untuk menyelesaikan satu produk.

\section{A. Perumusan Masalah}

Dari latar belakang diatas dapatlah dirumuskan masalah sebagai berikut :

1. Berapa waktu baku di stasiun meja makan?

2. Berapa jumlah produksi standar meja makan?

3. Berapa beban kerja tenaga kerja dan jumlah tenaga kerja yang diperlukan untuk menyelesaikan pekerjaan meja makan?

\section{B. Batasan Masalah}

Karena adanya keterbatasan waktu, dana dan tenaga maka penelitian ini memberikan batasan adalah :

1. Penelitian hanya dilakukan pada Assembling Departement khususnya stasiun meja makan di PT. XY Gudang Catur Harjo. Stasiun meja makan penggunaan tenaga manusia lebih dominan dibanding tenaga mesin.

2. Produk yang digunakan dalam penelitian adalah meja makan dengan kode produksi DT Marco.

3. Pengukuran kerja hanya dilakukan dengan menggunakan metode work sampling.

\section{Tujuan Penelitian}

Tujuan yang ingin dicapai dari penelitian ini adalah :

1. Menentukan waktu baku di stasiun meja makan.

2. Menentukan jumlah produksi standar meja makan.

3. Menentukan beban kerja stasiun meja makan dan jumlah tenaga kerja yang diperlukan untuk menyelesaikan pekerjaan meja makan.

\section{LANDASAN TEORI}

\section{A. Pengertian Proses Produksi}

Proses produksi adalah suatu metode atau cara tahapan-tahapan untuk menciptakan atau membentuk suatu barang dari bahan baku menjadi barang setengah jadi atau barang jadi menggunakan peralatan atau mesin sehingga barang tersebut mempunyai nilai tambah, tidak lupa bahwa untuk melakukan kegiatan tersebut juga memerlukan dana, tentu saja dana yang digunakan dalam proses produksi harus yang serendahrendahnya.

\section{B. Perencanaan Produksi dan Tenaga Kerja}

Tujuan dari perencanaan produksi adalah membuat keputusan yang baik mengenai hal-hal yang perlu dilaksanakan, dan bagaimana cara melaksanakannya. Perencanaan dilakukan pada masa kini untuk masa yang akan datang. Perencanaan dapat membantu memberikan arah yang perlu ditempuh dalam pencapaian tujuan.

Perencanaan tenaga kerja dapat didefinisikan berdasarkan hasilnya atau porsi pelaksanaannya. Berdasarkan hasilnya perencanaan tenaga kerja adalah suatu proses untuk membuat rencana kebijakan dan program ketenagakerjaan. Sedangkan dilihat dari permasalahannya, ketenaga-kerjaannya yang terjadi pada waktu sekarang dan masa yang akan datang, serta usaha-usaha merumuskan kebijakan dan program yang relevan untuk mengatasinya. 


\section{Pengukuran Waktu Kerja}

Penelitian kerja dan analisis kerja pada dasarnya akan memuaskan perhatian pada bagaimana suatu pekerjaan akan diselesaikan. Dengan mengaplikasikan prinsip dan teknik pengaturan cara kerja yang optimal dalam sistem kerja tersebut, maka akan diperoleh alternatif metode pelaksanaan kerja yang dianggap memberikan hasil yang paling efektif dan efisien. Pekerjaan telah dapat dikerjakan secara efisien waktu penyelesaian berlangsung paling singkat, untuk itu perlu diterapkannya prinsip-prinsip dan teknik-teknik pengukuran kerja. Pengukuran kerja ini akan berlangsung dengan usaha-usaha untuk menetapkan waktu baku yang dibutuhkan untuk menyelesaikan suatu pekerjaan. Waktu baku ini sangat diperlukan terutama untuk (Wignjosoebroto, 1995) :

a. Perencanaan kebutuhan tenaga kerja.

b. Estimasi biaya-biaya untuk upah tenaga kerja.

c. Penjadwalan produksi dan penganggaran.

d. Indikasi keluaran produk yang mampu dihasilkan seorang tenaga kerja.

e. Perencanaan sistem pemberian bonus dan insentif bagi karyawan berprestasi.

Waktu baku merupakan waktu yang dibutuhkan seorang pekerja yang memiliki kemampuan rata-rata dalam penyelesaian suatu pekerjaan.

\section{Pengukuran Kerja dengan Metode Sampling Kerja (Work Sampling)}

Sampling atau dalam bahasa asingnya sering disebut dengan Work Sampling, Ratio Delay Study, atau Random Observation Method adalah suatu teknik untuk mengadakan sejumlah besar pengamatan terhadap aktivitas kerja dari mesin, proses atau pekerja / operator. Pengukuran kerja dengan metode sampling kerja ini seperti halnya pengukuran kerja dengan jam henti (stop-watch time study) diklasifikasikan sebagai pengukuran kerja secara langsung karena pelaksanaan kegiatan pengukuran harus secara langsung ditempat kerja yang diteliti.

Secara garis besar metode sampling kerja ini akan dapat digunakan untuk :

1. Mengukur "Ratio Delay" dari sejumlah mesin, karyawan/operator, atau fasilitas kerja lainnya.

2. Menetapkan "Performance Level" dari seseorang selama waktu kerjanya berdasarkan waktu-waktu dimana orang ini bekerja atau tidak bekerja terutama sekali untuk pekerjaan-pekerjaan manual.

3. Menentukan waktu baku untuk suatu proses / operasi kerja seperti halnya yang bisa dilaksanakan oleh pengukuran kerja lainnya.

\section{E. Keuntungan Menggunakan Metode Sampling}

Dalam melaksanakan tugas-tugas pengukuran waktu kerja sering dijumpai yang terdiri dari pos-pos yang harus diperiksa sedemikian banyaknya, sehingga tidak sepadan lagi perbandingan antara waktu, tenaga dan biaya penelitian yang dicurahkan dengan hasil yang hendak dicapai.Adapun keuntungan menggunakan metode sampling kerja dalam pengukuran beban kerja adalah :

a. Metode sampling dapat menghemat biaya, waktu, dan tenaga.

b. Memungkinkan untuk mengadakan evaluasi yang objektif.

\section{F. Prosedur Pelaksanaan Sampling Kerja.}

Metode sampling kerja sangat cocok digunakan dalam melakukan pengamatan atas pekerjaan yang sifatnya tidak berulang dan yang memiliki siklus, waktu yang relatif panjang. Pada dasarnya prosedur pelaksanaannya cukup sederhana, yaitu melakukan pengamatan aktivitas kerja untuk selang waktu yang diambil secara acak terhadap satu atau lebih mesin / operator dan kemudian mencatatnya apakah mereka ini dalam keadaan bekerja atau menganggur (idle).

\section{G. Penggunaan Tabel Bilangan Acak Dalam Sampling Kerja}

Untuk melakukan pengamatan dalam sampling kerja maka masing-masing kejadian yang diamati selama aktivitas kerja berlangsung harus memiliki kesempatan yang sama untuk diamati. Dengan kata lain pengamatan haruslah dilaksanakan secara 
acak (random). Untuk maksud ini maka penggunaan tabel angka acak (random number tabels) barang kali merupakan metode yang terbaik guna menjamin bahwa sampel pengamatan yang diambil benar-benar dipilih secara acak..

Tabel bilangan acak terutama sekali dapat dipakai sebagai alat untuk menetapkan waktu setiap harinya dimana pengamatan harus dilakukan.

\section{H. Penentuan Frekuensi Pengamatan}

Frekuensi pengamatan pada hakekatnya tercantum pada jumlah pengamatan yang diperlukan dan waktu yang tersedia pada pengumpulan data yang direncanakan. Sebagai contoh apabila diketahui bahwa 3600 kali pengamatan harus dikerjakan dan kemudian direncanakan untuk diselesaikan dalam waktu 30 hari, maka setiap hari kerja akan diperlukan 3600/30 yaitu sebesar 120 kali pengamatan. Dengan demikian maka pengamatan kerja yang harus dilaksanakan sebanyak 120 kali perhari kerja. (secara random) dimana waktu pengamatan ini dipilih dari daftar angka random.

\section{Penentuan Jumlah Pengamatan yang dibutuhkan.}

Banyaknya pengamatan yang harus dilakukan dalam sampling kerja akan dipengaruhi oleh 2 faktor utama, yaitu :

1. Tingkat ketelitian (degre of accuracy) dan hasil pengamatan.

2. Tingkat kepercayaan (level of convidence) dari hasil pengamatan.

Dengan asumsi bahwa terjadinya kejadian seorang operator akan bekerja atau menganggur mengikuti pola distribusi normal, maka untuk mendapatkan jumlah sample pengamatan yang harus dilaksanakan dapat dicari berdasarkan rumus berikut (Wigjosoebroto, 1995) :

$$
\mathrm{Sp}=\mathrm{k} \sqrt{\frac{P(1-P)}{N}}
$$

$$
\mathrm{N}^{\prime} \quad=\quad\left(\frac{k}{s}\right)^{2} \quad \frac{1-P}{P}
$$

dengan :

$\mathrm{s} \quad=$ Tingkat ketelitian yang dikehendaki dan dinyatakan dalam desimal

$\mathrm{P} \quad=$ Prosentase terjadinya kejadian yang diamati dan juga dinyatakan dalam desimal

$\mathrm{N}=$ Jumlah pengamatan yang harus dilakukan untuk sampling kerja

$\mathrm{k}=$ Harga indeks yang besarnya tergantung dari tingkat kepercayaan yang diambil

Untuk tingkat kepercayaan $68 \%$ harga $\mathrm{k}$ adalah 1

Untuk tingkat kepercayaan $95 \%$ harga k adalah 2

Untuk tingkat kepercayaan $99 \%$ harga $\mathrm{k}$ adalah 3

\section{J. Penentuan Tingkat Ketelitian dan Tingkat Kepercayaan.}

Pengukuran yang ideal adalah pengukuran yang dilakukan sebanyak mungkin sehingga hasilnya semakin mendekati keadaan yang sebenarnya. Mengingat adanya keterbatasan waktu, biaya dan tenaga yang cukup besar yang hasilnya dapat dipercaya.

Tingkat ketelitian menunjukkan penyimpangan maksimal hasil pengukuran dari waktu penyelesaian yang sebenarnya, sedangkan tingkat keyakinan menunjukkan besarnya keyakinan pengukur bahwa hasil yang diperoleh memenuhi syarat ketelitian yang telah ditetapkan. Sebagai contoh tingkat ketelitian $5 \%$ dari rata-rata sebenarnya dan kemungkinan untuk mendapatkan hasil seperti ini adalah $95 \%$. Pengukuran memperoleh rata-rata pengukuran yang menyimpang lebih dari $5 \%$ seharusnya, hal ini dibolehkan terjadi hanya dengan kemungkinan $5 \%$ (100\%-95\%). 


\section{K. Pemakaian Peta Kontrol dalam Sampling Kerja (Work Sampling)}

Peta kontrol atau control chart secara umum telah banyak digunakan dalam statistical quality control dapat pula digunakan dalam pelaksanaan sampling kerja. Dengan menggunakan peta kontrol ini maka kita akan dapat melihat secara jelas kondisi-kondisi kerja yang tidak wajar.

Metode sampling kerja ini dikembangkan berdasarkan hukum probabilitas, karena itulah maka pengamatan suatu obyek tidak perlu dilaksanakan secara menyeluruh tetapi cukup dengan menggunakan contoh (sample) yang diambil secara acak (random). Agar kesimpulan yang diambil lebih tepat, yaitu tidak sekedar mengira-ngira, diperlukan teknik tertentu secara statistik dikenal sebagai sampling perbandingan populasi atau sampling for estimatis population propotion.

Untuk itu maka peta kontrol yang digunakan adalah peta kontrol proporsi atau propotion control chart, garis sentralnya dalam sample sedangkan garis-garis batasnya adalah sebagai berikut (Wignjosoebroto, 1995) :

a. Batas kontrol atas

$$
\mathrm{BKA}=\mathrm{P}+\mathrm{k} \sqrt{\frac{P(1-P)}{N}} .
$$

b. Batas kontrol bawah

$$
\mathrm{BKB}=\mathrm{P}-\mathrm{k} \sqrt{\frac{P(1-P)}{N}}
$$

dengan :

$\mathrm{P}=\quad$ Prosentase rata-rata untuk proporsi kejadian yang diamati dan dinyatakan dalam bentuk desimal.

$\mathrm{N}=\quad$ Jumlah pengamatan yang dilakukan per siklus waktu kerja.

$\mathrm{k}=\quad$ Tingkat kepercayaan yang digunakan.

Kemudian data-data yang telah diperoleh dipetakan kedalam peta kontrol yang telah ditentukan garis sentralnya, batas kontrol atas (BKA) dan batas kontrol bawah (BKB) sehingga akan terlihat apakah proses sudah berlangsung menurut spesifikasi yang dikehendaki.

$$
\mathrm{P}=\frac{P i}{X}
$$

dengan :

$\mathrm{Pi}=$ Presentase kejadian dihari ke- $\mathrm{i}$

$\mathrm{X}=$ Jumlah hari pengamatan

Rumus yang digunakan untuk menghitung jumlah pengamatan rata-rata yang dilaksanakan per siklus waktu kerja adalah sebagai berikut : (Wignjosoebroto, 1995)

$$
\mathrm{n}=\frac{n i}{X}
$$

dengan :

$\mathrm{ni}=$ Jumlah pengamatan yang dilakukan pada hari ke-i

$\mathrm{X}=$ Jumlah hari pengamatan.

\section{Penetapan Waktu Longgar dan Waktu Baku.}

Waktu normal untuk suatu elemen operasi kerja adalah semata-mata menujukan bahwa seorang operator yang berkualifikasi baik akan bekerja menyelesaikan pekerjaan pada kecepatan/tempo kerja yang normal. Waktu longgar yang dibutuhkan dan mengiterupsi proses produksi ini bisa diklasifikasikan menjadi personal allowance, fatigue allowance, dan delay allowance. Waktu baku yang akan ditetapkan harus mencakup semua elemen-elemen kerja dan ditambah dengan kelonggaran-kelonggaran (allowance) yang perlu. Dengan demikian maka waktu baku adalah sama dengan waktu normal kerja ditambah dengan waktu longgar. 


\section{Perhitungan Waktu Baku}

Metode work sampling harus diestimasikan terlebih dahulu performance rating dari operator yang diamati dan waktu longgar yang ada prosentase produktif tiap pekerja dihitung terlebih dahulu sebelum menghitung waktu baku, rumus yang dipergunakan untuk menghitung prosentase produktif tiap pekerja adalah :

$$
\text { Prosentase Produktif }=\frac{\text { Jumlah Produktif }}{\text { Jumlah Pengamatan }}
$$

Data-data yang telah dikumpulkan dan telah mengalami proses pengujian keseragaman dan kecukupan data selanjutnya digunakan untuk menghitung waktu baku. Waktu baku dihitung setelah waktu siklus dan waktu normal diketahui terlebih dahulu. Rumus yang digunakan untuk menghitung waktu siklus dan waktu normal dan waktu baku adalah sebagai berikut :

$$
\begin{aligned}
& \text { Waktu siklus }=\frac{\text { Total Waktu } \mathrm{x} \text { W aktu Kerja }}{\text { Jumlah Produk Yang Dihasilkan }} . \\
& \text { Waktu normal }=\frac{\text { Total Waktu } \mathrm{x} \text { W aktu Kerja } \mathrm{x} \text { P }}{\text { Jumlah Produk Yang dihasilkan }}
\end{aligned}
$$

$$
\text { Waktu baku }=\text { Waktu Normal } \mathrm{x} \frac{100 \%}{100 \%-\text { Kelonggara } \mathrm{n}(\%)}
$$

\section{N. Perhitungan Produksi Standar}

Produksi standar merupakan hasil bagi antara jumlah jam kerja yang digunakan dengan waktu baku pengerjaan per unit. Jumlah jam kerja yang digunakan disini merupakan jumlah jam kerja selama pengamatan dilakukan. Rumus yang digunakan untuk perhitungan produk standar (Wignjosoebroto 1995) :

$$
\text { Produksi Standar }=\frac{\text { Jam Kerja Yang Digunakan Selama Pengamatan Dilakukan }}{\text { Waktu Baku Pekerjaan Perunit }}
$$

\section{O. Beban Kerja}

Beban kerja adalah banyaknya pekerjaan (operasi) yang harus dikerjakan untuk menyelesaikan satu pekerjaan tertentu. Untuk menentukan beban kerja yaitu menghitung prosentase produktif dari pengamatan aktivitas kerja. Sedangkan prosentase produktif didapatkan dari pengamatan produktif dibagi pengamatan aktivitas kerja. Pengamatan aktivitas kerja terdiri dari pengamatan produktif dan pengamatan idle.

\section{P. Jumlah Tenaga Kerja yang diperlukan}

Peramalan kebutuhan tenaga kerja sangat erat hubungannya dengan peramalan kondisi perusahaan dimasa yang akan datang. Banyak sedikitnya masing-masing jenis tenaga kerja yang diperlukan akan tergantung pada prospek ekonomi perusahaannya dan kebijaksanaan perusahaan dalam melakukan investasi peralatan / mesin-mesin yang akan dipakai dalam produksinya.

\section{METODOLOGI PENELITIAN}

Tahapan penelitian dalam metodologi dapat digambarkan dalam bentuk diagram alir penelitian seperti pada gambar 1 .

\section{ANALISA DATA DAN PEMBAHASAN}

\section{A. Perhitungan Prosentase produktif untuk Pekerja Satu}

Sebelum melakukan test kecukupan data dan test keseragaman data terlebih dahulu melakukan perhitungan prosentase produktif untuk setiap pekerja di stasiun meja makan. Persamaan yang digunakan untuk menghitung prosentase produktif adalah persamaan 7. 


$$
\begin{aligned}
P & =\frac{154}{165} \\
& =0,9333
\end{aligned}
$$

Hasil perhitungan prosentase produktif untuk pekerja satu sebesar 0,9333 sedangkan untuk pekerja yang lain dapat dilihat pada lampiran 5. Hasil Perhitungan Prosentase produktif akan digunakan untuk test kecukupan data dan test keseragaman data.

\section{B. Pengujian Kecukupan Data}

Untuk memperoleh tingkat ketepatan yang dikehendaki dapat digunakan test kecukupan data. Untuk mendapatkan jumlah pengamatan yang harus dilakukan adalah persamaan 2. Perhitungan kecukupan data yang dilakukan merupakan perhitungan untuk pekerja stasiun meja makan. Pemakaian $\mathrm{k}=2$ supaya data pengamatan tidak banyak atau sedikit. Perhitungan dibawah ini merupakan contoh perhitungan test kecukupan data untuk pekerja satu pada stasiun meja makan :

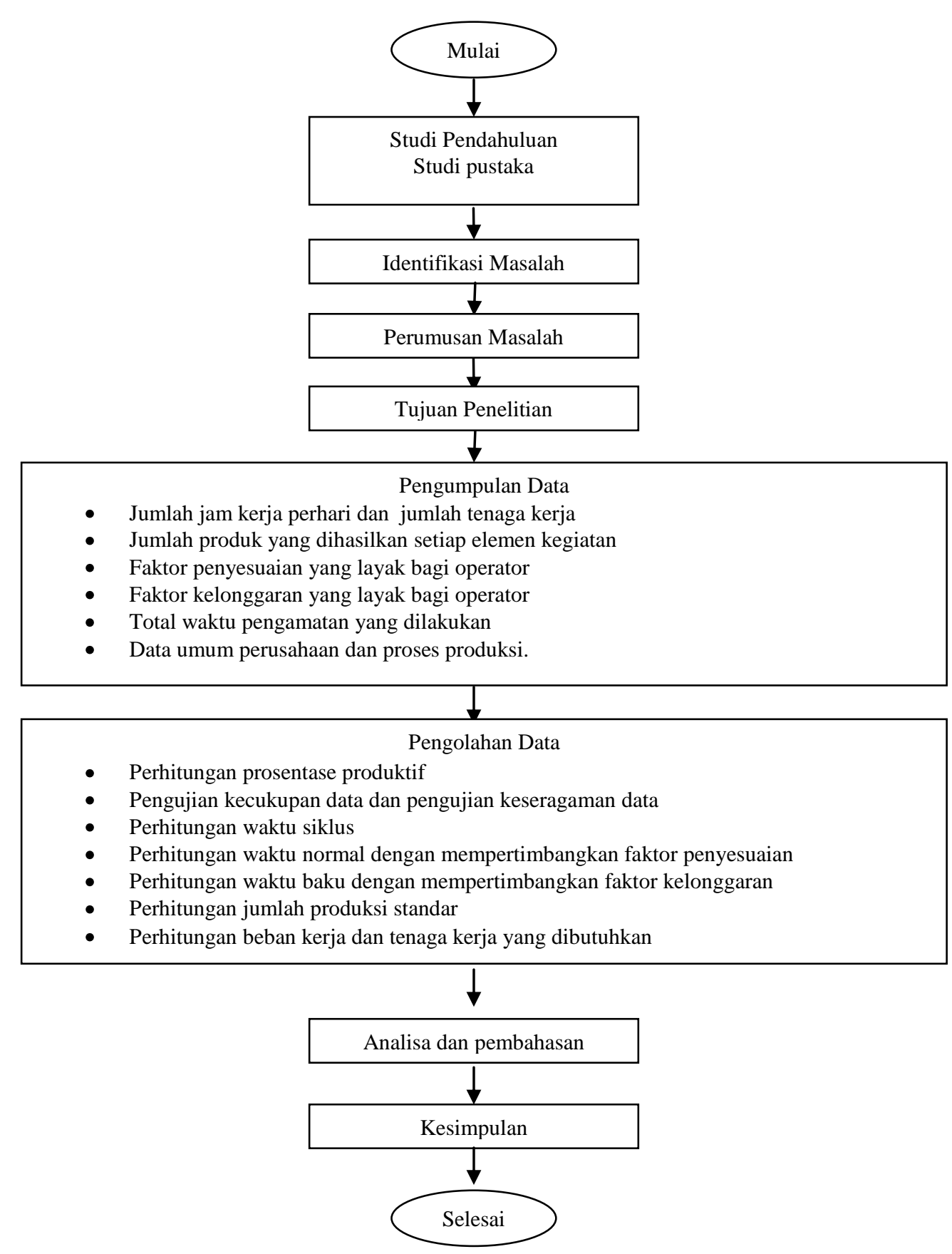


Gambar 1. Diagram Alir Penelitian

$$
\begin{aligned}
\mathrm{N}^{\prime} & =\left(\frac{2}{0,05}\right)^{2} \times \frac{1-0,9333}{0,9333} \\
& =114 \text { pengamatan }
\end{aligned}
$$

Hasil diatas menunjukkan bahwa $\mathrm{N}^{\prime}<\mathrm{N}$ berarti data sudah mencukupi

Tabel 1. Test Kecukupan Data stasiun meja makan

\begin{tabular}{|c|c|c|c|}
\hline Pekerja & $\begin{array}{c}\text { Jumlah Data } \\
\text { Teoritis (N') }\end{array}$ & $\begin{array}{c}\text { Jumlah Data } \\
\text { Pengamatan }(\mathrm{N})\end{array}$ & Keterangan \\
\hline 1 & 114 & 165 & $\mathrm{~N}^{\prime}<\mathrm{N}$ data sudah cukup \\
\hline 2 & 148 & 165 & $\mathrm{~N}^{\prime}<\mathrm{N}$ data sudah cukup \\
\hline
\end{tabular}

\section{Pengujian Keseragaman Data}

Untuk menghitung keseragaman data adalah persamaan 3 dan persamaan 4 . Prosentase produktif rata-rata untuk pekerja satu pada stasiun kerja meja makan sebesar 0,9329 dan untuk pekerja yang lain dapat dilihat pada lampiran 5, sedangkan jumlah pengamatan rata-rata sebesar 33 yang diperoleh dari hasil perhitungan dibawah ini :

$$
\mathrm{N}=\frac{33+33+33+33+33}{5}=\frac{165}{5}=33
$$

Maka perhitungan test keseragaman data sebagai berikut :

$$
\begin{aligned}
& \mathrm{BKA}=\mathrm{P}+\mathrm{k} \sqrt{\frac{P(1-P)}{N}} \\
& \begin{aligned}
&=0,9333+2 \sqrt{\frac{0,9333(1-0,9333)}{33}} \\
&=1,0201 \\
& \mathrm{BKB}=\mathrm{P}-\mathrm{k} \sqrt{\frac{P(1-P)}{N}} \\
&=0,9333-2 \sqrt{\frac{0,9333(1-0,9333)}{33}} \\
&=0,8464
\end{aligned}
\end{aligned}
$$

Perhitungan batas kontrol atas (BKA) dan batas kontrol bawah (BKB) untuk setiap pekerja dapat dilihat pada lampiran 5. Data-data selengkapnya dari seluruh pekerja dapat dilihat pada tabel berikut ini :

Tabel 2. Test Keseragaman Data Stasiun Meja Makan

\begin{tabular}{|c|c|c|c|}
\hline Pekerja & $\begin{array}{c}\text { Batas Kontrol } \\
\text { Atas (BKA) }\end{array}$ & $\begin{array}{c}\text { Batas Kontrol } \\
\text { Bawah (BKB) }\end{array}$ & Keterangan \\
\hline 1 & 1,0201 & 0,8464 & Data didalam batas kontrol \\
\hline 2 & 1,0121 & 0,8180 & Data didalam batas kontrol \\
\hline
\end{tabular}

Setelah di lakukan perhitungan keseragaman data, maka langkah selanjutnya adalah membuat gambar grafik batas kontrol. Grafik dibawah ini merupakan contoh grafik batas kontrol untuk pekerja satu pada stasiun meja makan. Sedangkan untuk pekerja yang lain dapat dilihat pada lampiran 5. Adapun contoh grafik batas kontrol untuk pekerja satu pada stasiun meja makan dapat dilihat pada gambar 2. Dari grafik di bawah dapat di jelaskan 
bahwa data yang diperoleh untuk pekerja satu pada stasiun meja makan berada dalam batas kontrol, karena terletak diantara batas kontrol atas dan batas kontrol bawah.

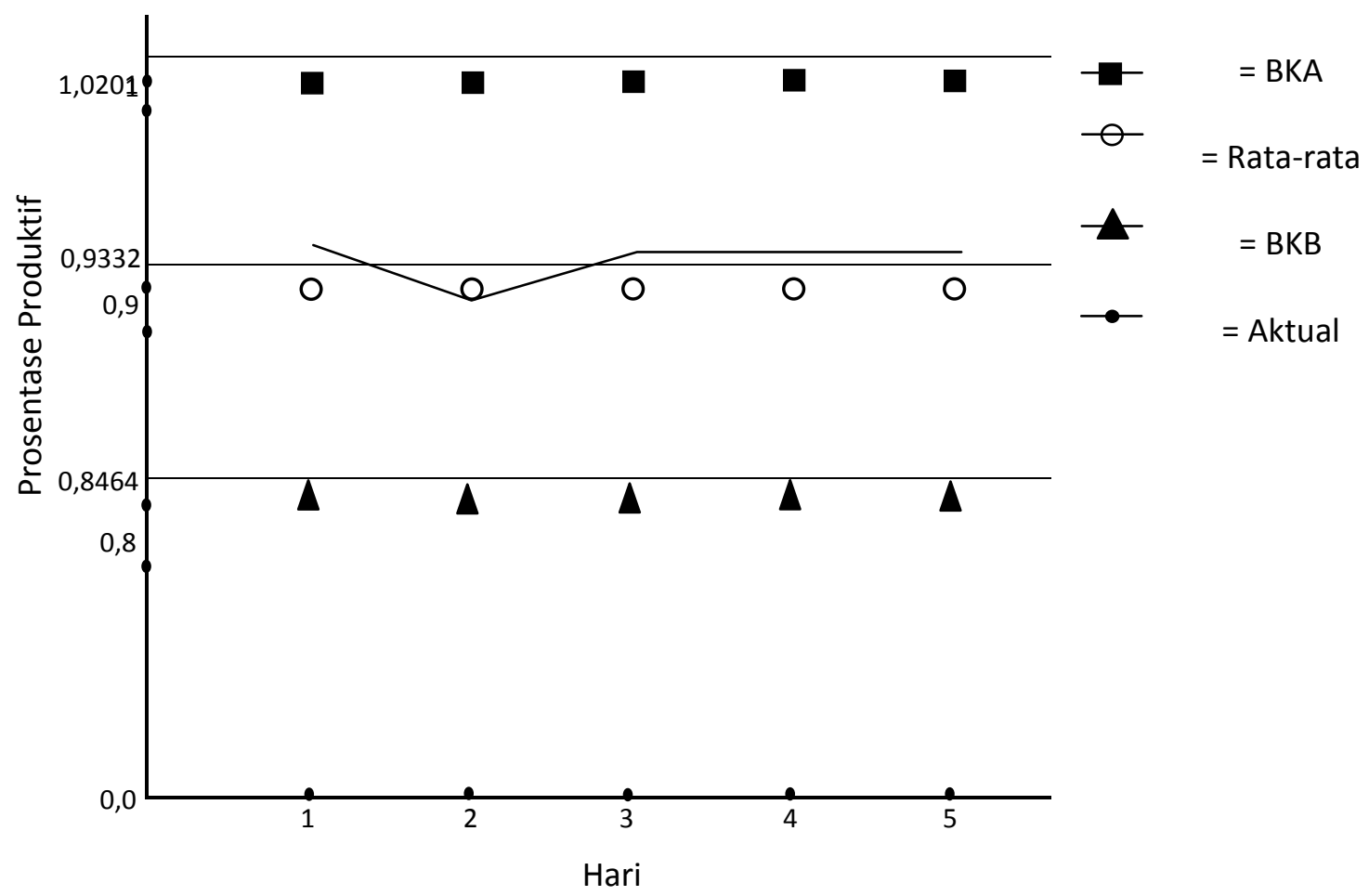

Gambar 2. Grafik Pengamatan Pekerja Satu Selama Lima Hari

\section{Perhitungan Waktu Baku}

Untuk menghitung waktu siklus adalah persamaan (2.8). Sedangkan rumus yang digunakan untuk menghitung waktu normal adalah persamaan (2.9). Adapun rumus yang digunakan untuk menghitung waktu baku adalah persamaan (2.10)

Langkah-langkah yang dilakukan dalam menghitung waktu baku adalah :

a. Menentukan jumlah kunjungan terhadap seluruh pekerja yang akan diamati.

b. Menentukan jumlah pengamatan produksi dan prosentase produktifnya.

c. Menetapkan jumlah menit pengamatan yang dilakukan selama pengamatan berlangsung.

d. Menghitung jumlah produk yang dihasilkan selama pengamatan

e. Menghitung waktu siklus

f. Menghitung waktu normal dengan memasukkan faktor penyesuaian.

g. Menghitung waktu baku dengan memasukkan faktor kelonggaran yang telah ditetapkan

Stasiun meja makan :

a. Jumlah kunjungan terhadap dua pekerja

Jumlah kunjungan $=165 \times 2=330$

b. Jumlah pengamatan produktif keseluruhan dan prosentase produktif. Jumlah pengamatan produktif keseluruhan $=305$

Prosentase produkif $=\frac{305}{330} \times 100 \%=92,42 \%$

c. Jumlah menit pengamatan yang dilakukan selama 5 hari

Jumlah menit pengamatan $=7$ jam $\times 5$ hari $\times 60$ menit $=2100$ menit

d. Jumlah produk yang dihasilkan selama pengamatan adalah 10 meja makan

e. Menghitung waktu siklus 
Waktu Siklus $=\frac{2100 \text { menit } \times 0,9242}{10}=194,08$ menit

f. Menghitung waktu normal

Waktu normal $=\frac{2100 \times 0,9242 \times 1,14}{10}=221,25$ menit

g. Menghitung waktu baku

Waktu baku $=221,13$ menit $\mathrm{x} \frac{100 \%}{100 \%-26 \%}=298,98$ menit

\section{E. Perhitungan Produksi Standar}

Produksi standar merupakan perbandingan antara jumlah jam kerja yang digunakan dengan waktu baku pengerjaan per unit. Jumlah jam kerja yang digunakan adalah 2100 sedangkan waktu baku 298,82 menit per unit, maka besarnya produksi standar adalah :

Produksi standar $=\frac{2100}{298,98}=7$ per lima hari unit meja makan

\section{F. Perhitungan Beban Kerja}

Prosentase produktif stasiun meja makan didapatkan dari jumlah pengamatan produktif dibagi jumlah pengamatan aktivitas kerja untuk dua tenaga kerja dalam menyelesaikan pekerjaan meja makan. Prosentase produktif ini sama dengan beban kerja yang harus dikerjakan tenaga kerja untuk menyelesaikan pekerjaan meja makan. Sedangkan pengamatan aktivitas kerja selama lima hari sudah melewati test kecukupan data dan test keseragaman data. Sehingga prosentase produktif dapat segera dihitung. Adapun perhitungan prosentase produktif stasiun meja makan adalah :

Prosentase produktif $=\frac{305}{330} \times 100 \%=92,42 \%$

Prosentase produktif stasiun meja makan adalah 92,42 \%. Jadi beban kerja untuk menyelesaikan pekerjaan meja makan di stasiun meja makan adalah 92,42\%.

\section{G. Perhitungan Jumlah Tenaga Kerja yang diperlukan}

Pada stasiun meja makan terdapat 2 pekerja untuk menyelesaikan pekerjaan meja makan. Untuk mendapatkan "man hours" di stasiun meja makan yaitu waktu baku meja makan 4,978 jam dikalikan 2 menjadi 9,956 jam.

PT XY Yogyakarta dalam satu bulan merencanakan untuk membuat 110 unit meja makan, sedangkan "man hours" 9,956 jam kerja tenaga kerja, maka ini berarti sama dengan beban kerja selama 1095,16 jam kerja tenaga kerja. Tenaga kerja dalam satu bulan bekerja 181,5 jam. Untuk menentukan jumlah tenaga kerja yang diperlukan yaitu beban kerja selama 1095,16 jam kerja tenaga kerja dibagi jam kerja tenaga kerja selama satu bulan 181,5 jam sama dengan 6 tenaga kerja. Jadi jumlah tenaga kerja yang diperlukan pada stasiun meja makan adalah 6 orang.

\section{H. Analisa Waktu Baku}

Waktu baku adalah waktu seluruhnya untuk menyelesaikan suatu pekerjaan pada prestasi standar. Hasil perhitungan waktu baku di departemen Assembling pada stasiun meja makan sebesar 298,98 menit. Waktu baku pada stasiun meja makan menunjukkan waktu yang dipergunakan untuk menyelesaikan satu unit produk meja makan membutuhkan waktu 298,98 menit. Sedangkan faktor kelonggaran $26 \%$ dipergunakan dalam perhitungan waktu baku supaya pekerja dapat bekerja dengan baik. Faktor kelonggaran yang diberikan dapat meningkatkan etos kerja tenaga kerja untuk menyelesaikan pekerjaan meja makan.

\section{Produksi Standar}

Perhitungan produksi standar merupakan perbandingan antara jumlah jam kerja yang digunakan dengan waktu pengerjaan perunit. Jumlah jam kerja yang digunakan 
selama pengamatan sebesar 2100 menit, sedangkan waktu baku sebesar 298,98 menit. Jadi produksi standar adalah 7 per lima hari unit meja makan.

\section{J. Analisa Beban Kerja}

\section{Beban Kerja Tenaga Kerja Stasiun Meja Makan}

Beban kerja tenaga kerja stasiun meja makan diperoleh dari prosentase produktif sebesar $92,42 \%$. Sedangkan prosentase produktif menunjukkan aktivitas pekerja untuk menyelesaikan pekerjaan meja makan. Kemudian ditetapkan standar jam kerja bagi pekerja adalah 7 jam per hari, maka hasil ini akan menunjukkan bahwa waktu yang dipakai untuk bekerja sebesar $92,42 \%$ x 7 jam $=6,469$ jam dan 0,530 jam sisanya akan terbuang sia-sia karena di sini pekerja tidak menunjukkan kegiatan yang produktif. Waktu bekerja 6,469 jam menunjukkan akivitas produksi terlalu padat dan pekerja tidak terpenuhi kebutuhan untuk melepas lelah sehingga tidak dapat menghasilkan performa terbaik. Menurut Sritomo Wignjosoebroto (1995, hal 216), prosentase waktu yang dipakai untuk kerja adalah $75 \%$ dan prosentase waktu mengangur (idle) adalah $25 \%$. Prosentase produktif lebih dari $75 \%$ terlalu berat bagi pekerja dalam melaksanakan aktivitas kerja. Jadi beban kerja 92,42\% terlalu berat bagi pekerja sehingga tidak mampu memenuhi target produksi.

\section{Jumlah Tenaga Kerja yang diperlukan}

Beban kerja tenaga kerja stasiun meja makan terlalu berat sehingga tidak mampu memenuhi target produksi. Tenaga kerja stasiun meja makan berjumlah dua orang tidak bisa menyelesaikan pekerjaan meja makan tepat pada waktunya. Untuk mengetahui jumlah tenaga kerja yang diperlukan maka harus menerjemahkan beban kerja ke dalam "man hours".

PT XY Yogyakarta dalam satu bulan merencanakan untuk membuat 110 unit meja makan, sedangkan "man hours" memerlukan 9,956 jam kerja tenaga kerja, maka ini berarti sama dengan beban kerja selama 1095,16 jam kerja tenaga kerja. Tenaga kerja dalam satu bulan bekerja 181,5 jam. Untuk menentukan jumlah tenaga kerja yang diperlukan yaitu beban kerja selama 1095,16 jam kerja tenaga kerja dibagi jam kerja tenaga kerja selama satu bulan 181,5 jam sama dengan 6 tenaga kerja. Jadi jumlah tenaga kerja yang diperlukan pada stasiun meja makan adalah 6 orang.

\section{KESIMPULAN}

Berdasarkan hasil penelitian, maka dapat ditarik kesimpulan sebagai berikut :

1. Waktu baku yang diperlukan untuk menghasilkan satu unit produk pada stasiun meja makan adalah 298,98 menit.

2. Produksi standar pada stasiun meja makan adalah 7 per lima hari unit meja.

3. Beban kerja tenaga kerja pada stasiun meja makan adalah $92,42 \%$ dan jumlah tenaga kerja yang diperlukan 6 orang.

4. Beban kerja yang dialami tenaga kerja pada stasiun meja makan terlalu besar sehingga perlu adanya perhatian yang serius dari pihak manajemen perusahaan untuk menstabilkan beban kerja dengan cara menambah empat tenaga kerja.

5. Manajemen perusahaan harus memperhatikan prestasi kerja tenaga kerja sehingga muncul etos kerja.

6. Tenaga kerja pada stasiun kerja meja makan dalam melaksanakan aktivitas produksi dituntut lebih profesional karena stasiun kerja ini sangat menentukan keberhasilan produk meja makan.

\section{DAFTAR PUSTAKA}

[1] Assauri, Sofyan (1999), Manajemen Produksi dan Operasi, Penerbit Fakultas Ekonomi Universitas Indonesia, Jakarta.

[2] Daryanto (1996), Mesin Perkakas Bengkel, Edisi Ketiga, Rineka Cipta, Malang. 
[3] Internasional Labour Office (1976), Penelitian Kerja dan Pengukuran Kerja, Penerbit Erlangga, Jakarta.

[4] Laboratorium Analisa Perencanaan Kerja, (2004) Modul Pratikum : Analisis Perancangan Kerja, Lab. APK dan Ergonomi Teknik Industri UWMY, Yogyakarta.

[5] Ranupandoyo Heidjrachman (1984), Manajement Personalia, BPFE UGM, Yogyakarta.

[6] Sutalaksana, Iftikar (1979), Teknik Tata Cara Kerja, ITB, Bandung

[7] Swasano, Y; Sulistiyaningsih (1983), Metode Perencanaan Tenaga Kerja, Penerbit BPFE, Yogyakarta.

[8] Wignjosoebroto, Sritomo (1989), Teknik tata cara dan pengukuran kerja, penerbit ITS, Surabaya

[9] Wignjosoebroto, Sritomo (1995), Ergonomi, Studi Gerak dan waktu, Penerbit Guna Widya, Jakarta.

[10] Wignjosoebroto, Sritomo (2003), Pengantar Teknik dan Manajemen Industri, Guna Widya, Jakarta. 